\title{
Grants-in-Aid Devolution to Uttar Pradesh during Post Reform India: A Critical Anatomy
}

\author{
Asha Srivastava $^{1} \&$ N. M. P. Verma ${ }^{1}$ \\ ${ }^{1}$ Department of Economics, Babasaheb Bhimrao Ambedkar University, Lucknow, India \\ Correspondence: N. M. P. Verma, Department of Economics, Babasaheb Bhimrao Ambedkar University, \\ Lucknow, India. Tel: 91-979-584-1945. E-mail: nmpverma@gmail.com
}

Received: August 12, 2013

Accepted: November 12, $2013 \quad$ Online Published: January 23, 2014

doi:10.5539/ijef.v6n2p197

URL: http://dx.doi.org/10.5539/ijef.v6n2p197

\begin{abstract}
The aim of federal transfers is to bring regional economic balance and provide equal social services to all irrespective of their place of residence as it is their constitutional right. In the era of globalization the existence of uniformity in all respects has become must for all over the nation irrespective of residing place. Due to economic planning the functions of state governments have increased considerably and this also increased the sphere of economic and social welfare administration. The existence of non-correspondence of resource and expenditures between centre and states is common to all federations. Increasing socio-economic functions which are expensive and expanding in nature has increased the responsibilities of state governments. The problem of increasing expenditure aggrieves due to disparity in the level of development of various states caused by man made efforts to increase revenue resources and differences in the endowment of resources given by the nature or natural resources. These situations bring the centre and states and different states in the problem of non-correspondence in a federation giving birth to Vertical Imbalances and Horizontal imbalances. The study is a normative one and therefore adopts finance commission data on devolution. This constraints the ability of the states to raise revenues and at the same time it increases their expenditures on socio-economic infrastructure. The transfer of resources through FC (Finance Commission) in form of Tax shares and Grants-in-Aid (henceforth GIA) has played a very crucial role in development of the states. UP the most populous state having nearly 20 crores people has received Rs 3235.1cr during IXth FC, Rs.2632.24cr during Xth FC, Rs. 4007.74cr. during XIth FC, Rs. 21694.12crores during XIIth FC and Rs.30805.9crores during XIIIth FC. These figures show increasing trend but in per capita terms it increased in the period of XIIth FC and XIIIth FC. GIA transfers as percent of GSDP increased sharply during XIIth FC to $9.4 \%$ but it decreased during XIIIth FC to $7.5 \%$. The paper with secondary data shows the pattern of devolution.It is based on normative approach of analysis.
\end{abstract}

Keywords: Indian federation, transfer of resources, fiscal imbalance, finance commission, grants-in-aid, regulatory reform

\section{Introduction}

Externalities arising from central policies on the states functioning gives pressure for increasing resources of the states and hence need of more funds. Just as central policies affect states' functions; the policies pursued by the central government affect the provision of public services of the state governments. The states are unable to completely discharge the functions assigned to them by the Central government in order to bring a number of subjects into the concurrent list and alter the allocation to the items of this list through shared cost programs or direct central spending.

The fiscal policy and monetary policy has to play vital crucial roles in reform of the economy. For faster economic growth of the economy a greater share of output is to be devoted to investment in order to expand infrastructure and business. The fiscal consolidation strategy needs to be saved and at the same time the quality of spending has to be improved. Now the challenge is to continue to reform process with the experience of past success and make the growth inclusive economy. The growth after 1980 has substantially reduced the national poverty. The millennium poverty goal is to half it by 2015 , while the government is aiming to achieve even higher medium term economic annual growth rate of 10 per cent. This goal can be achieved with additional structural reform. An inclusive growth can be achieved by increasing the prosperity of poorer states whose economy has slower pace of expansion than the richer states. The poverty of poorer states can be lowered down 
by reducing their difficulties. There exists a difference in economic performance of the states. The poorer states require measures to improve infrastructure, education and basic services and this in return will increase the potential for growth outside of agriculture. This will boost up the better paid employment which is the key to economic growth and lowering down the poverty for spreading income and growth potential more widely a comprehensive reform package is essential. A number of sectors of the economy have become more dynamic due to recent reforms but there are some sectors of the economy which need reforms. Mainly these sectors are the provision of infrastructure, labor and financial markets, growth in product where reforms are needed at the central and state levels. In order to create a truly national market and improve incentives and release resources, the bottlenecks in infrastructure have to be reduced which is the great constraint of growth. The education sector has to be improved efficiently in order to improve human capital formation. There are some areas which will boost growth of the economy which has to be focused and paid due attention. Monetary policy is focusing on lowering inflation over the medium term. The expansion started in 2003 has led to an imbalance between supply and demand despite 9 per cent GDP growth reaching in 2006. The fiscal deficit has been reducing substantially.

A fiscal transfer is becoming determinant and has to play vital role in income redistribution towards poorer states. India having so many diversities needs a good system of revenue sharing. The government's spending across the states is extremely large. Inter-governmental transfers reduce spending inequalities. The transfer system should be simplified, administration should be improved and transparency in fiscal transfers is very essential. Incentives towards fiscal discipline have to be promoted while borrowing has to be restricted. Different modes of resource transfer have different impact.GIA transfers can be very useful to balance the fiscal imbalance. This is normative study based on post reform FC devolution data. An attempt has been here to analyze critically the devolution to UP State.

\section{Literature Review}

Federal transfers are necessary part of economic development and it holds different opinions. Different federations prefer different methods of resource transfers to solve the problem of fiscal imbalance as this is common to all federation and the objective behind is to provide maximum social advantage to all irrespective of place of residence (Srivastava \& Verma, 2012).

Chandrasekhar, S. (1983) argues, it is opined that the federal transfers are designed to bring about a degree of regional economic balance and a modicum of equality in social services as a matter of constitutional guarantee in terms of equity, growth and redistributive justice. The states are in better position to spend as they know even the very smallest need and situations of the smallest section of the society. Rao and Das Gupta (1995) also argued that the states may be used as spending agencies also because of their comparative advantage in implementation. In poverty alleviation schemes, for example, the states are better placed to implement policies as they can identify the poor, and initiate policy suited to the prevailing conditions which vary from region to region. Thus states are in more need of financial resources.

Federations have the objective to provide maximum social advantage to all irrespective of place of their residence. Rao (2010) describes fiscal reforms at the State level are, thus, important from the view point of macro-economic stability and micro-economic allocation efficiency. The system of inter-governmental fiscal transfers, as it has evolved in India over the years, has come under attack on the ground that it has created perverse incentives by putting a premium on equity and neglect of efficiency that led to a fiscal profligacy at lower levels of government, although sharp regional disparities persist and have grown sharper particularly in recent years.

Bagchi, Chelliah and associates (2001) argue that the existence of increasing decentralization of expenditure and increasing centralization of revenues in India has led to the widening up of the fiscal imbalance. Warner argues that in Germany, social welfare expenditures are shared responsibility where the Central Government sets the broad outlines of policy (criteria and level of spending), while the local government makes the determination of social neediness and disburse grants. In addition to the transfers recommended by the State Finance Commissions, the local governments receive funds for the implementation of various central schemes. The most important is for poverty alleviation, but there are also other schemes for social and community services in which the local governments have a comparative advantage in implementation. Even apart from conditional grants, local governments have very little flexibility in the use of funds (Rao, Amar, \&Vani, 2003). Normative theories of fiscal federalism postulate that inter-government transfers should be determined by equity and efficiency considerations, to support local governments in providing differentiated public goods to heterogeneous populations, while ensuring an even distribution of basic services across all regions (Musgrave, 1959; 1983; 1997; Oates, 1972; Gramlich, 1977). A more recent literature focuses on the inefficiencies created by local 
taxation due to inter-jurisdictional tax competition and mobility that creates a valuable role for central taxation and regional distribution via grants-in-aid (Inman \& Rubinfeld, 1996). However, empirical evidence shows that such normative theories lack explanatory power because central decisions about the regional distribution of resources actually take place within a political economy context where national legislators are elected from regional constituencies, and political bargaining within the legislature determines outcomes (Weingast, 1979; Shepsle, 1979; Weingast, Shepsle, \& Johnsen, 1981; Baron \& Ferejohn, 1989; Becker, 1983). The service provision in this context mean are limited to merit goods like education and health services provided by government, law and order situation in the state, general administration, etc. Hence the principles for grants-in-aid may therefore be used for education, Health natural calamities rural development, local bodies and maintenance expenditure (Hajra, Rakhe, \& Gajbhiye, 2008). Thus for these reasons the above studies have been carried out. The present study will further add up the existing literature with reference to India which has been done so far.

Process of development depends on economic and social infrastructure of a state. There are hard challenges for an undeveloped state to proceed on the developmental path. UP being a poor, populous and undeveloped state has to face many constraints for development. These limitations can't be separated and both develop simultaneously. All the social sectors are very complex and have deep linkages across them. Health, education communication and infrastructure are closely related and is still of high priority for the process of development. Thus the mono objective of this paper is to evaluate the role of grants-in-aid transfers to Uttar Pradesh for removing fiscal imbalance. The hypothesis is that Uttar Pradesh received the largest share in grants-in-aid transfers compared to other low income states. This hypothesis has been tested in this paper with processing of devolution data of FC for the post reform period.

\section{Equitable Criterion of Devolution}

State governments have always had very significant responsibilities (for law and order, infrastructure development, health, education, agriculture-to name just a few) while the centre has less to do. At the same time states have not had commensurate powers either to raise resources or to influence broader trends that create the context or enabling conditions for fulfilling these responsibilities.

After establishment of Planning Commission the planned expenditure has shown increasing trend from the very beginning till date. Consequently the resource transfer through Finance Commission declined. More plan transfers were made through Planning Commission. Later on it was noticed that Plan transfers were not made on equitable basis the richer states were gainer while the poorer states were the sufferer. The richer states were benefited more from plan transfers who also enjoy better infrastructure. Poor states have little resources to invest on their infrastructure needs. Per capita plan expenditure in richer states is higher while the poor states have to satisfy with low per capita plan expenditure. This again widened the gap between rich and poor states and the inter-state disparity increased especially during the reform period. To fill the gap between rich and poor states, an equitable criterion of devolution is needed. Measures are necessary for reorientation of public expenditure in rich and poor states. Economic and social policies have to work together for the upliftment of states and reducing the inter-state disparity. Centre enjoys more revenue resources while states have more expenditure sources. The financial sources of centre and states are different; the centre has got elastic sources of revenue while the states have inelastic sources of revenue. The economy is variable, sometimes it faces boom and sometimes recession, the fiscal situation of the government also changes. The planned and unplanned needs of the states also change with the changing circumstances and changing economic situation of the country. Hence any constitutional provisions and rule will not apply in all conditions and every time. It has to change accordingly. The economic infrastructure also changes with time. In Indian constitution demarcation of functional responsibilities is provided and the finances of centre and states are also demarcated. "India has sometimes been characterized as only a "quasi-federation". For the dimension of governance the government has to work as provider of public goods and corrector of externalities. Within the particular constitutional framework, more specific laws may be changed more easily, by legislative action. Administrative rules and ordinances are the least durable. Any constitutional aspect can have implication for both equity and efficiency.

The major fiscal indicators of the state governments show the need of fiscal transfers. States show deficits depending upon their socio-economic and natural conditions. Fiscal and monetary policies affect the financial situation of the government. The centre has power to restrict and limit states borrowing, because states have to obtain the permission of central government for any borrowing because normally every state is indebted to the centre. In India's legal arrangements for the control of state level borrowing, there is no constitutional or statutory rules on balanced operating budgets. There are no penalties on state officials that violate balanced budget rules. For governing borrowing by lower level governments, ex-ante registration of state borrowing with 
central government is required. There is no national policy that provides state borrowing is only backed by the full faith and credit of the issuing state. There is no explicit and credible ban on bail outs of states at risk of defaulting on debt by national government. There is no national policy that prescribes rigorous accrual accounting standards of states. These are the loopholes of rules that govern borrowing by lower level governments in Indian federal system. In India there is no national legal restriction on the ability of states to borrow to finance consumption expenditure. There is no nationally set ceiling on the overall debt of the states. There are no national laws that explicitly restrict the central government guarantee of state borrowing and forbid the bailout of states that default on debt. There is no law that forbids states from guaranteeing loans. In order to eliminate revenue deficits almost all states have now introduced Fiscal Responsibility Act. This act is to prohibit borrowing to finance consumption. There is a profound shift in economic management in India since the mid-1980s Indian economy has progressively moved successive reforms towards a market based system. Liberalization has touched on most aspects of economic policy which includes fiscal policy, financial market regulation, industrial policy and trade and foreign investment. The overall reform has a very beneficial impact on the Indian economy. Potential output growth is $8 \frac{1}{2}$ per cent annually and now India has become third largest economy in the world. Increased economic growth has helped in reducing poverty which is reducing in absolute terms. Areas such as communication insurance, asset management and information technology, where government regulation has been eased significantly or liberalized output has grown rapidly, with exports of information technology. This enabled services particularly strong competition which has been opened to infrastructure sectors in those areas and private sectors have proved to be extremely effective and growth oriented. States with a relatively liberal regulatory environment has better economic performance while at the same level states with restrictive regulatory environment have not good economic performance. Some reforms have well responded but the next round of reforms needs to focus on a number of key areas because of existence of some significant problems. The Indian economy has been transformed by fundamental reforms. India has moved away from its former model and has become a market based economy over the past two decade. The main cause is that the direct tax rates were significantly reduced, elimination of industrial activity by pervasive government licensing and restrictions on investment by large companies were closed. The economy was opened for competition and the process of reform continued.. The most important part was improvement of fiscal discipline by enactment of fiscal responsibility laws like FRBM Act for the central government and state governments. These reforms had a major beneficial impact of the economy. The combined fiscal deficit of central government and state governments has reduced remarkably from 2002 to 2010 . It was 10 per cent in 2002 , 6 per cent of GDP in 2006 and to about 4.5\% of GDP in 2010. The ratio of debt to GDP fell from 82 per cent in 2004 to 75 per cent by March 2007; GDP per capita is raising by 7.5 per cent annually, a rate which is just double in a decade. Now India is becoming the third largest economy of the world after USA and China in 2006 due to faster growth. The economic performance has improved due to reforms.

In India the states are in need of resource transfer to carry out their developmental goals and to improve their economic conditions. The fiscal health of states shows deficits among all states as percent of GDP. (Figure 1.)

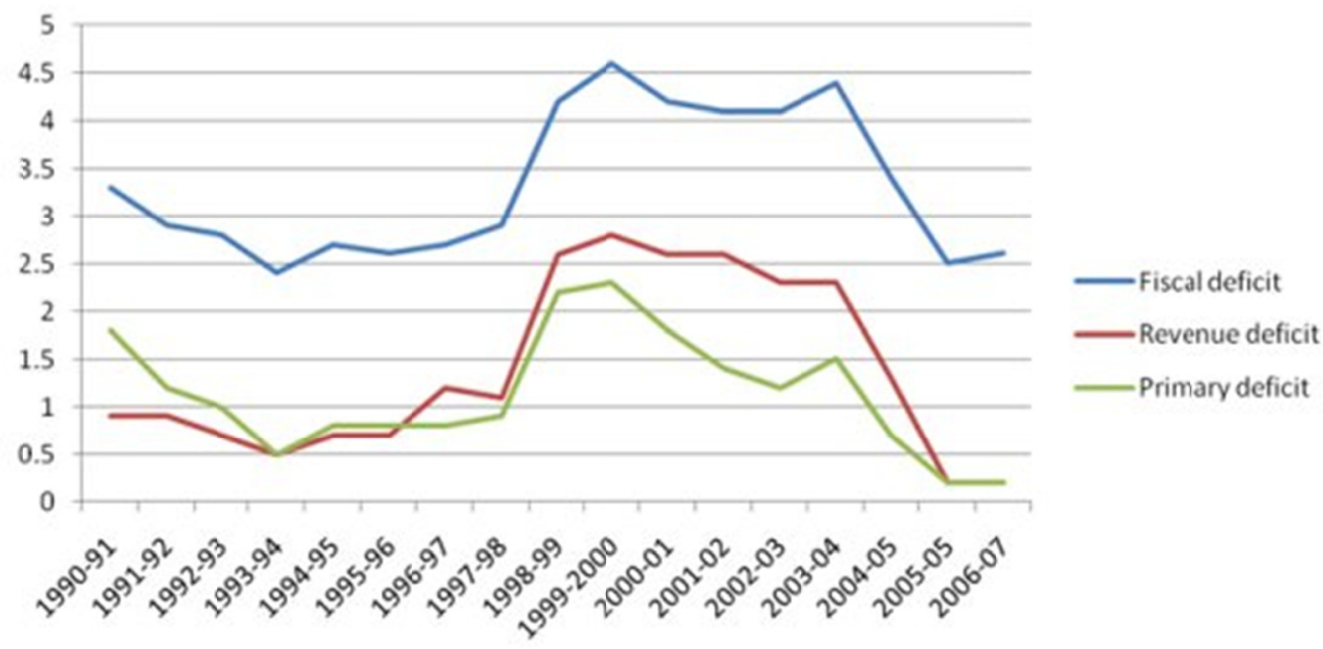

Figure 1. Deficit indicators of all state governments (as percent of GDP) 
The fiscal health of states leads to financial devolution. Figure 1 describes the pattern of deficit among all state governments taken together. It is evident that the severe fiscal crisis of the states that was so marked in the early years of this decade is no longer as pervasive. Since 2004 all the major deficit indicators have been declining, and the revenue and primary deficits are now close to zero for the states as a whole. Even the fiscal deficit total is under 3 per cent of GDP. It is generally supposed that this improved fiscal health is the result of the Eleventh Finance Commission's award, which is perceived to have substantially increased grants to states and also allowed some debt write-off to those states that agreed to pass the controversial fiscal responsibility legislation.

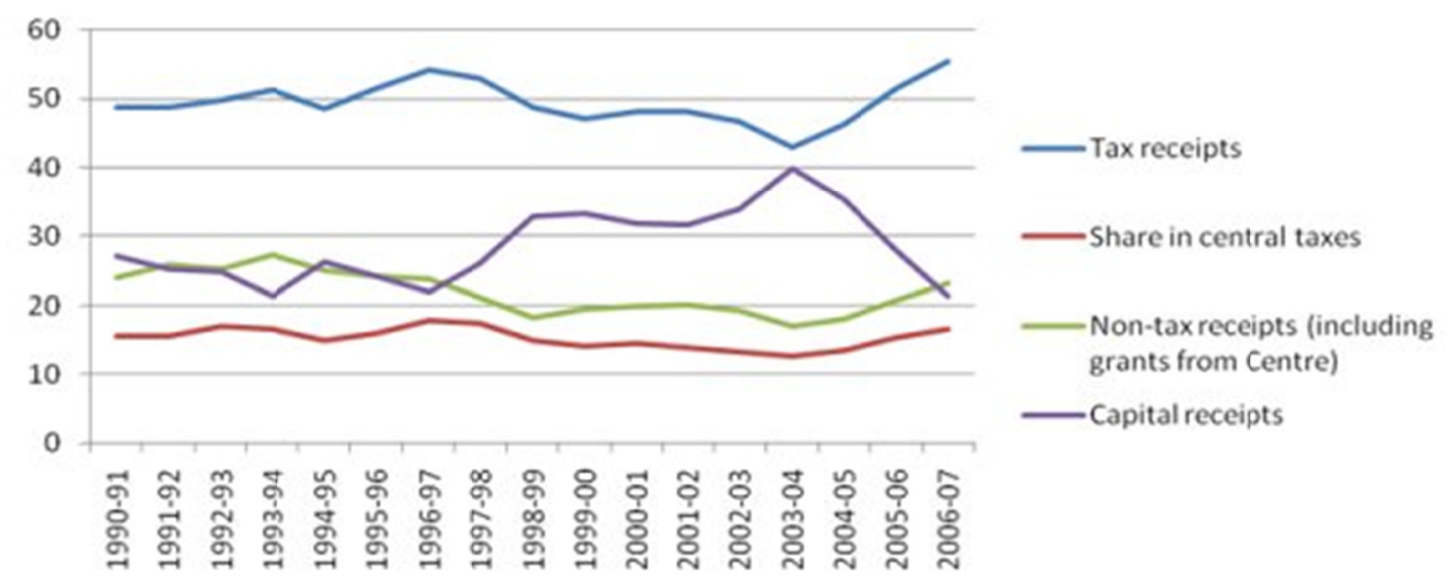

Figure 2. Composition of total receipts state governments (percent)

Figure 2 indicates that In fact, the significant increase has been in tax receipts of the state governments themselves, which in 2006-2007 accounted for more than 55 per cent of their total fiscal resources while the capital receipts reduced to 20 per cent during this period. Now for the grants from the centre the states received about 20 percent but it decreased in the period 1999-2005, again it showed slight improvement in 2006-2007. The states get their revenue from Tax receipts, Capital Receipts, Non Tax receipts and share in central taxes.

\section{Resource Transfer Mechanism}

In addition to transfer of resources from the Centre to the States according to the recommendations of the Finance Commission, there are two other sources of transfer:

(1) Assistance for Plan purposes from the Planning Commission,

(2) Discretionary grants from the Centre to the States.

These sources of transfer have contributed substantially more resources than statutory transfers (which are transfers through the Finance Commission) and reflect the considerable power that the Central government enjoys in influencing the decision-making process at the State level.

For most of the period of planning, statutory transfers have remained less than one-third of total transfers, the remaining two-thirds having been contributed by the Planning Commission as assistance for Plan purpose or by the Central Government under the head of 'discretionary grants'.

Though the Planning Commission had no statutory basis (as against the Finance Commission which is a body statutorily set up to recommend devolution of resources from the Centre to the States), it tended to take up the functions of the Finance Commission and for a considerable period of planning, has remained the more important source of transfer. By vesting residuary powers in the Centre and by keeping 47 items in the concurrent list strengthened the base of Central control and vested the Central government with practically unlimited powers to interfere in the governance of States. Under the new formula, it is stated that 30 per cent of total Plan assistance would be given in the form of grants and 70 per cent in the form of loans (General Category States).This keeps the states for more loan burden. This provision did not apply to Jammu and Kashmir, Assam and North-Eastern States, Special Category States in whose case 10 percent was to be given in the form of loans and rest 90 per cent in the form of grants.

However transfers through the Finance Commission contribute only about one-third of the total transfers from the Centre to the States. The rest are channeled through the Planning Commission and discretionary grants from 
the Centre to the States.

This has led to arbitrary distribution with backward states suffering a disadvantage and has led to an erosion of state autonomy. The revenue raising capacity of the states is also restricted because of the nature of the taxes assigned to them.

\section{Fiscal Imbalances}

Fiscal imbalance is common to all states but its nature varies. In some states this imbalance has deep roots but very essential to balance.

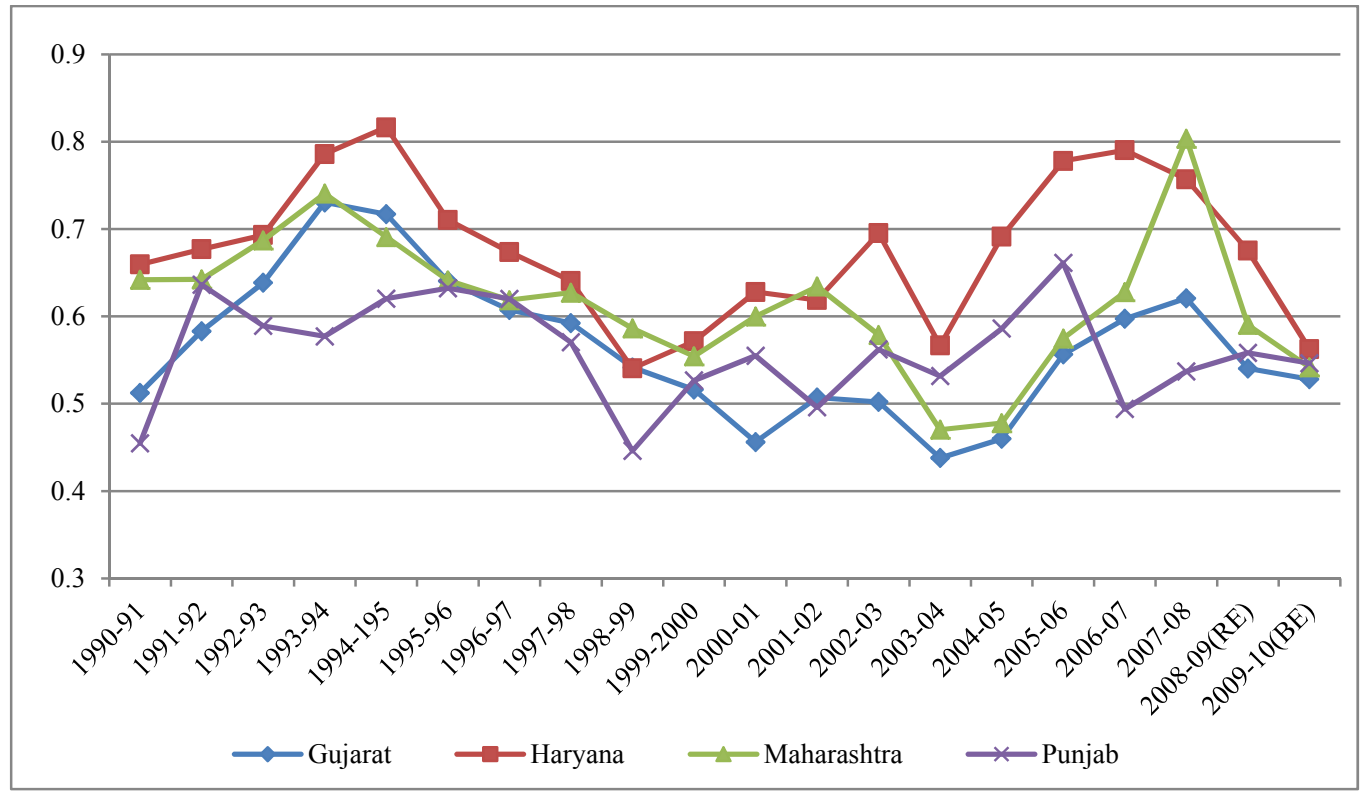

Figure 3. Fiscal imbalance among high income states

The existence of imbalance is common to all states. High income states also face this problem but at lesser extent due to better infrastructure and favour of resource transfer. Among high income states Haryana is least affected with this problem and Punjab facing ups and downs in fiscal health but in 2009-2010 all the four developed states reached at the same point of imbalance.

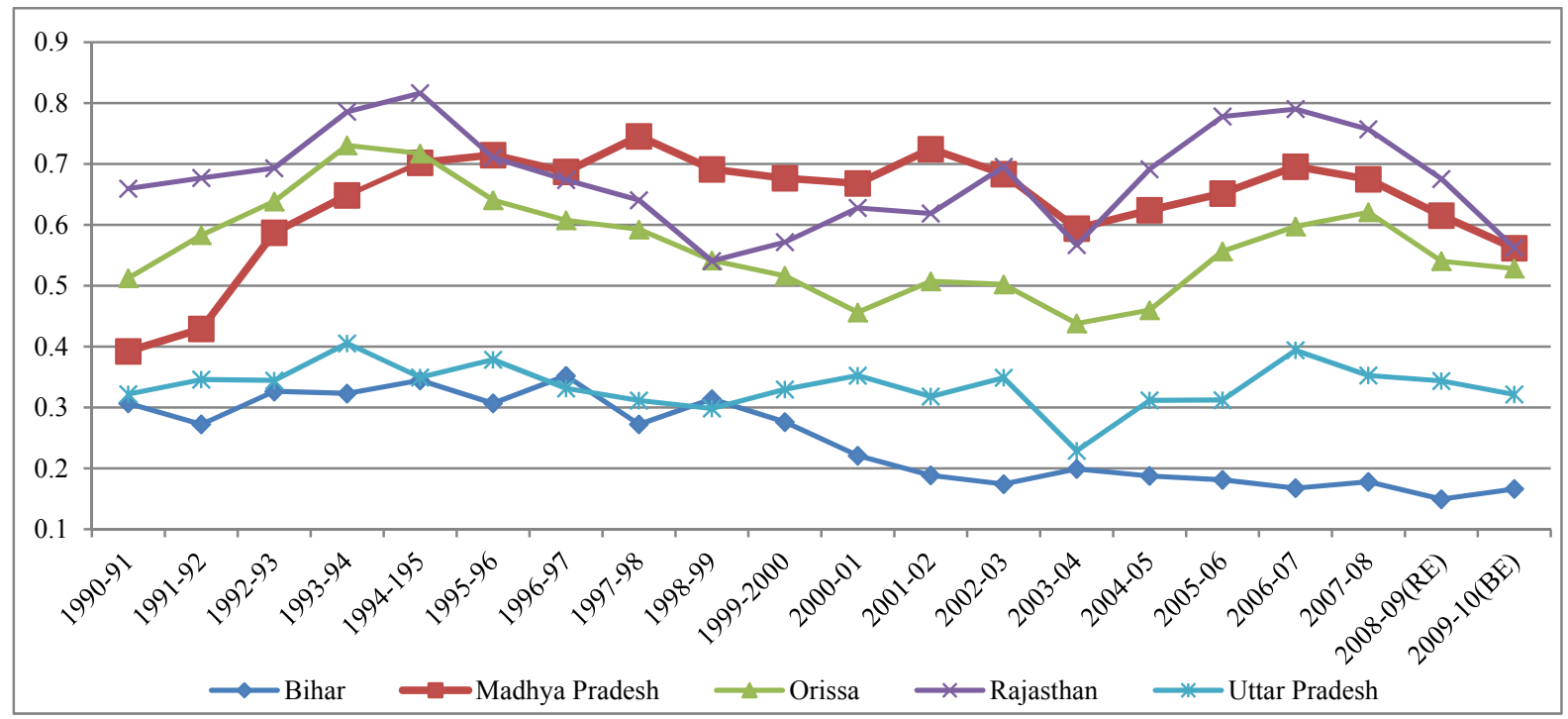

Figure 4. Fiscal imbalance among low income states 
Fiscal imbalance exists among low income states also but the level of imbalance differs among the states. Bihar having the highest imbalance among the low income states and UP has slightly improved fiscal health as compared to Bihar

The scope of the Finance Commission should therefore be enlarged to reduce the interference of the Centre in the financial management of the States. In the context of raising revenues the recommendation of the Tenth Finance Commission to increase the role of industry, needs to be seriously considered.

There are some important constraints on following a full-fledged equalization approach:

i) The extent of disparities in fiscal capacities is very large, and the required re-distribution through transfers would be very large.

ii) If a minimum amount of vertical transfer is to be made including the richer states, the required amount of total transfer would also be very large.

iii) Existence of multiple channels of transfers makes it difficult to develop an integrated approach to transfers.

iv) There are various data problems in following an equalization approach even at a macro level.

The dependence on Central transfers may vary across States depending on the Capacity to generate own resources. For the high-income States, the dependence on Central transfers varies from one-fourth to one-sixth of their revenue receipts. In respect of the middle-income States, the dependence on Central transfers is between one-third to one-fifth except in the case of Chhattisgarh and West Bengal, where the dependence is much higher (40 to 50 Per cent). The dependence of low income States is much higher and varies in the range of 42 to 80 per cent. The dependence on Central transfers is much higher in the case of special category States. In these States, the dependence varies from 64.98 per cent to 92.95 per cent of their revenue receipts

\subsection{Grants-In-Aid to UP}

The GIA transfers to UP changed from time to time according to the TOR given by the government. From ninth FC after the adoption of normative approach the trend of GIA transfers changed.

Table 1. GIA and UP

\begin{tabular}{llllll}
\hline UP and GIA & $\begin{array}{l}\text { IXth FC } \\
1990-1995\end{array}$ & $\begin{array}{l}\text { Xth FC } \\
1990-1995\end{array}$ & $\begin{array}{l}\text { XIth F } \\
2000-2005\end{array}$ & $\begin{array}{l}\text { XIIth FC } \\
2005-2010\end{array}$ & $\begin{array}{l}\text { XIIth FC } \\
2010-2015\end{array}$ \\
\hline GIA to UP & 3235.1 & 2632.24 & 4007.74 & 21694.12 & 30805 \\
Per Capita GIA & 223.01 & 160.46 & 220.54 & 1086 & 1414.4 \\
Per Capita tax dev. & 956.6 & 2043.7 & 4099.7 & 6205.9 & 13834.5 \\
Per Capita dev through FC & 1202.9 & 2204.2 & 4320.2 & 6681.4 & 15253 \\
GIA as\% of GSDP & 2.96 & 3.48 & 2.6 & 9.4 & 7.5 \\
\hline
\end{tabular}

The above Table shows the GIA transfers to UP during successive FCs. The amount of GIA transfers changed and increased in nominal terms. Till eleventh FC the per capita GIA remained low but the twelfth and thirteenth FC increased it largely. The per capita tax devolution and per capita FC transfers also increased. The GIA as \% of GSDP increased heavily during twelfth FC but it reduced in the period of thirteenth FC.

\subsection{Change in Per Capita GIA Transfers}

Table 2. GIA transfers to UP and low income states Rs.crores

\begin{tabular}{lllll}
\hline Low income States & Tenth F.C. & Eleventh F.C. & Twelfth F.C. & Thirteenth F.C. \\
\hline Bihar & -28.1 & 32.45 & 847.71 & 183.75 \\
Madhya Pradesh & -37.46 & 6.04 & 407.23 & 267.22 \\
Orissa & -26.69 & 45.41 & 225.28 & -976.87 \\
Rajasthan & -40.08 & -109.7 & 32.95 & 1113 \\
Uttar Pradesh & -26.32 & -7.42 & 640.8 & 99.64 \\
\hline
\end{tabular}


The GIA transfers to UP was most favorable in the period of twelfth FC but it reduced in the thirteenth FC. During tenth and eleventh FC period it was in negative i.e. it reduced over the previous FC.

Table 3. Share of UP in GIA transfers among low income states (Rs.Cr)

\begin{tabular}{llllllll}
\hline Finance Commissions & Bihar & $\begin{array}{l}\text { Madhya } \\
\text { Pradesh }\end{array}$ & Orissa & Rajasthan & $\begin{array}{l}\text { Uttar } \\
\text { Pradesh }\end{array}$ & $\begin{array}{l}\text { Av. GIA transfers of } \\
\text { to low income states }\end{array}$ & $\begin{array}{l}\text { Av. Share low } \\
\text { income state UP }\end{array}$ \\
\hline Ninth (1989-1990) & 81.95 & 954.34 & 618.61 & 651.3 & 2163.42 & 893.92 & 1269.5 \\
Ninth (1990-1995) & 11044.8 & 7582.29 & 5346.79 & 6060.62 & 17111.64 & 9429.22 & 7682.35 \\
Tenth (1995-2000) & 1353.11 & 818.47 & 923.14 & 1145.61 & 2632.24 & 1374.51 & 1257.73 \\
Eleventh (2000-2005) & 1793 & 1739.4 & 1727.86 & 2992.75 & 4007.74 & 2452.15 & 1555.59 \\
Twelfth (2005-2010) & 11008.61 & 7129.31 & 5273.3 & 4643.91 & 21694.12 & 9949.85 & 11744.27 \\
Thirteenth (2010-2015) & 21841.2 & 19500 & 9658.8 & 12949.8 & 30805.9 & 16611.14 & 14194.76 \\
\hline
\end{tabular}

The above table shows the condition of UP among other low income states in receiving GIA during ninth FC to thirteenth FC. The condition of UP among low income states was favorable and it received high GIA transfers during all the FCs but the rate of increase from the average transfer decreased.

\section{Conclusion}

A fiscal transfer is becoming determinant and has to play vital role in income redistribution towards poorer states. India having so many diversities needs a good system of revenue sharing. The government's spending across the states is extremely large. Inter-governmental transfers reduce spending inequalities and provide maximum social welfare to all irrespective of place of residence. The transfer system should be simplified, administration should be improved and transparency in fiscal transfers is very essential. Incentives towards fiscal discipline have to be promoted while borrowing has to be restricted. The Grants-in-Aid transfer should be based on objective and need of the State not on the TOR given to FC and needs more freedom. It should be simple and mostly focused on single objective.

All Finance Commissions gave undue importance to budgetary needs while deciding the allocation of grants-in-aid. They did not realize that advanced States could also incur large budgetary deficits (even deliberately at times) and qualify for larger grants-in-aid. This led to a paradoxical situation in some instances as richer States got more grants-in-aid as compared to poorer states.

The resource transfers through discretionary grants are not guided by any distinct philosophy of helping the poorer States to a greater extent. It is guided more by political consideration than by anything else. In any case, discretionary grants also do not seem to have helped the backward States more than the advanced States.

The process of resource transfers through the Planning Commission and the Finance Commission has failed in correcting the "horizontal imbalance" among the federating units, and disparities in their per capita incomes are growing. Plan assistance is provided up to 70 per cent in the form of loans and 30 per cent in the form of grants.

Since the ratio is a fixed one and does not discriminate between advanced and backward States, it amounts to discrimination against backward States. Since advanced States have a relatively better economic position they; should be granted a greater percentage of resources in the form of loans while backward States should receive a larger percentage in the form of grants.

Noncompliance to this common sense logic has resulted in a paradoxical situation where the comparatively richer States received a higher per capita grant than poorer states.

\section{References}

Archana, R. D. (2010). A comment on the distribution formula of the $13^{\text {th }}$ finance commission. Economic and Political Weekly, XLV(31).

Bagchi, A. K. (2001). The common minimum program: The finance commission of state governments and the urgent task of repair and reconstruction in India. An Economic Reform Agenda for 2004, New Delhi, Sahmat.

Chandrashekhar, S. (1983). Fiscal performance of Andhra Pradesh. Anvesak, IV(1). 
Chelliah, R. J. (1981). Trends and issues in Indian federal finance. New Delhi: NIPFP, Allied Publishers.

Government of India. (1993). Report of the tax reform public committee.

Government of India. (2004). Report of the $12^{\text {th }}$ Finance Commission.

Government of India. (2009). Fiscal situation and reforms. Agenda for the New Government, Ministry of Finance.

Kumudini, S., Hajra, R. P. B., \& Dhirendra, G. (2008). Issues before the thirteenth finance commission: Correction of vertical and horizontal imbalances. Economic and Political Weekly, 94.

Musgrave, R. A. (1997). Devolution, grants and fiscal competition. Journal of Perspectives, (4), 65-72.

Oates, W. E. (1972). Fiscal federalism. New York: Harcourt Brace Jovanovich.

Rao, H. (2006). Fiscal federalism-issues and policies. New Century Publication.

Rao, M. G. (2010). The $13^{\text {th }}$ finance commission's report: Conundrum in conditional ties. Economic and Political weekly, XLV(48), 46.

Srivastava, A., \& Verma, N. M. P. (2012). Grants-in-aid devolution in Indian democratic federation: Need of some suggested regulatory reforms. International Journal of Economics and Business Modeling, 2(2), $108-117$.

Sury, M. M. (2007). Fiscal policy developments in India: 1947 to 2007. New Delhi: Indian Tax Foundation.

Vithal, B. P. R., \& Shatry, M. L. (2001). Fiscal federalism in India. OUP, 56-57.

Warner. (2006). Inter-municipal co-operation in the USA regional governance solution? Urban Public Economics Review, 7, 132-151.

\section{Copyrights}

Copyright for this article is retained by the author(s), with first publication rights granted to the journal.

This is an open-access article distributed under the terms and conditions of the Creative Commons Attribution license (http://creativecommons.org/licenses/by/3.0/). 